\title{
MIGRAÇÃO SUL-SUL
}

\begin{tabular}{ll} 
Título & $\begin{array}{l}\text { Nuevos destinos de la migración africana reciente: los } \\
\text { senegaleses en Argentina }\end{array}$ \\
Autor/es & $\begin{array}{l}\text { Bernarda Zubrzycki } \\
\text { Con este trabajo pretendemos aportar al conocimiento } \\
\text { de un nuevo fenómeno vinculado a la movilidad humana: } \\
\text { las migraciones africanas subsaharianas hacia Sudamérica } \\
\text { en general, y migraciones senegalesas hacia Argentina en } \\
\text { particular. Nos centraremos en caracterizar la migración } \\
\text { senegalesa hacia Argentina, las motivaciones para migrar y las } \\
\text { formas de ingresar al país. }\end{array}$ \\
Ano/Edição & $\begin{array}{l}\text { Ano XXVI, no 72, jan-jun/2013. São Paulo } \\
\text { Título }\end{array}$ \\
Autor/es & $\begin{array}{l}\text { Novas rotas da migração Sul-Sul: o caso dos peruanos no } \\
\text { Brasil }\end{array}$ \\
Resumo & $\begin{array}{l}\text { Camila Daniel } \\
\text { Este artigo tem como objetivo refletir sobre a dinâmica } \\
\text { de mobilidade dos peruanos para o Brasil. Analisando seu } \\
\text { perfil e as principais motivações que os impulsionam a ir } \\
\text { para o exterior, indica-se que, ao contrário do que o senso } \\
\text { comum imagina, a população peruana no Brasil é diversa e } \\
\text { heterogênea, incluindo desde trabalhadores em atividades } \\
\text { informais, até profissionais altamente qualificados, oriundos } \\
\text { das mais diferentes partes do país, com múltiplos níveis de } \\
\text { escolaridade, que (re)produzem uma "cultura de migração». } \\
\text { O artigo se baseia em pesquisa bibliográfica e no trabalho de } \\
\text { campo realizado com peruanos no Rio de Janeiro. } \\
\text { Ano XXVI, no 73, jul-dez/2013. São Paulo }\end{array}$ \\
\hline Ano/Edição
\end{tabular}

\section{MULHERES}

Título

A migração de mulheres do ale do Jequitinhonha para São Paulo: de camponesas à proletárias

Autor/es

Maria Aparecida de Moraes Silva

Resumo

O objetivo deste trabalho é apresentar, a partir de dados preliminares de uma pesquisa que estamos desenvolvendo com mulheres migrantes do Vale do Jequitinhonha para a agricultura paulista (região de Ribeirão Preto), algumas reflexões sobre o processo de transformação social que afeta milhares 